\title{
Origins and development of Congress
}

All legislative Powers herein granted shall be vested in a Congress of the United States, which shall consist of a Senate and House of Representatives. (The Constitution of the United States of America, Article 1, Section 1)

\section{The origins of the Constitution}

In 1787, when the Founding Fathers of the United States of America crafted the Constitution - a Constitution which still endures today - they chose for the very first article, not the institution of the President or the Supreme Court, but the US Congress. The Constitution gave Congress the power to make laws for the federal government, the ability to check the actions of the President and the responsibility of representing the American people.

Constitutions are never written in a vacuum. They reflect the beliefs, goals and ambitions of their authors, and in many cases, the values of society. In this way the American Constitution is no exception. What is exceptional about the document, which British Prime Minister William Gladstone once described as 'the most wonderful work ever struck off at a given time by the brain and purpose of man', is that over 200 years after its conception it still forms the basis of the 
government of the United States. Consequently, to be able to understand the principles on which the US Congress was founded, one must first understand the politics which surrounded the formation of the United States of America.

The founding of British colonies in what was known as the 'new world' is only one part of the history of the Americas, but it is central to the history of the United States. It was from the British colonies that, in 1776, a new nation was born.

The first British colonists arrived in what is now Virginia in 1585. Life was difficult in the new world and many of the early colonies succumbed to disease, famine and attack by indigenous 'Indian' tribes. The first colony to overcome these difficulties and survive was established in Jamestown, Virginia in 1607. Their success was due to two factors: surviving the first winter with the aid of friendly Native Americans and an ability to grow tobacco. The colonists had discovered a mix of Caribbean and mainland American tobacco leaves which was appealing to the European palate and trade with the 'old world' had become both possible and profitable. By 1732, thirteen colonies had been established up and down the eastern seaboard of North America. These colonies began to thrive through trade and soon found a degree of autonomy from the British Government (throughout this time Britain had been more concerned with the aftermath of its own civil war than with the affairs of the colonists in the West). Colonial assemblies were established in America and these began to check the power of the resident royal governors, often taking control of aspects of taxation and expenditure. Gradually, the principles of self-government were becoming established in the minds of the colonists.

As the eighteenth century progressed, the British Crown and Parliament once again began to look to the West. The col- 
onies had proved to be a success and Britain wanted to expand their control of the continent. Their attempts at westward expansion, however, meant conflict with French forces who had established a powerful position in North America. The 'French Indian War' lasted from 1754 to 1763, until defeat for the French forces left the British in control of a large area of what is now Canada and the United States. The cost of the war and the resources needed to control their newly expanded western empire put a strain on British finances and led Parliament to look for new ways to raise revenue. Having decided that the colonies should pay more for their own defence, the British Parliament passed a series of Acts which levied taxes on colonial trade. Two taxes caused particular resentment among the colonists. The Sugar Act of 1764 banned the import of rum, placed a duty on molasses imported from non-English areas and introduced taxes on wines, silks, coffee and other luxury items. A year later, the Stamp Act taxed all newspapers, pamphlets, licenses, leases and other legal documents, a measure which affected anyone who did business. Other initiatives introduced by the British included a ban on credit notes and a requirement that the colonies provide royal troops with provisions and barracks.

The British actions had threatened the ability of the colonies to trade freely and, given the historical importance of trade to the colonies' existence, caused a great deal of resentment. Central to the complaint was the fact that the colonies had no representation in Parliament - the body that had instigated the taxes which had provoked the conflict. A call for 'no taxation without representation' lay at the heart of their grievances. Over the next ten years protests over British taxation and coercion grew, occasionally breaking into violence. Matters came to a head in Lexington, Massachusetts in 1775 
when a raid by British troops on colonial militias led to fullscale fighting and the start of the American Revolution.

A formal Declaration of Independence was issued on 4 July 1776. Largely written by Thomas Jefferson of Virginia, the Declaration set out the grounds on which the colonies claimed their right to throw off British rule. They charged that the history of King George III's rule was

a history of repeated injuries and usurpations, all having in direct object the establishment of an absolute Tyranny over these States ... In every stage of these Oppressions We have Petitioned for Redress in the most humble terms: Our repeated Petitions have been answered only by repeated injury. A Prince whose character is thus marked by every act which may define a Tyrant, is unfit to be the ruler of a free people.

Behind the Declaration were the ideas of eighteenth-century philosophers and writers such as Thomas Paine and John Locke, which were prevalent among the aristocracy of the time. Particularly influential was Locke's social contract theory (see Box 1.1). These ideas would go on to play a large part in the writing of the Constitution.

The War of Independence formally ended in 1783 with the signing of the Treaty of Paris in which the British Crown acknowledged the independence, freedom and sovereignty of the thirteen former colonies. With victory assured, the thirteen states were faced with the task of devising a system of government. Having just defeated what they viewed as a despotic power, the leaders of the new states had no intention of replacing the British Crown with their own monarch or creating a central government with the power to deny any state its rights ever again. However, it was recognised that some form of central administration was inevitable if the new indepen- 


\section{Box 1.1 John Locke and the social contract}

Seventeenth-century philosopher John Locke was one of the key architects of the social contract theory. Locke argued that governments were formed with the consent of its citizens. The people agreed to obey the government (thus surrendering some of their freedom to act as they choose) on the understanding that government would use its power to protect their natural rights of 'lives, liberties and estates'. The power of the individual to enforce the 'laws of nature' by administering punishments on those who broke them (up to and including the death penalty) was surrendered to the government. On the other side of the contract, if the government broke its promise and failed to respect the basic rights of the citizenry, it lost its own legitimacy and could be overthrown by the people.

It was partly on this basis that the Declaration of Independence stated that the British Crown had, through abusing the rights of the American colonists, forfeited its right to govern. It was then the duty of the American people to rise up against their British rulers and to institute their own government. This task was completed with American victory in the War of Independence.

dent states were to succeed. The result was the Articles of Confederation, drawn up in 1776, adopted in 1777, and which came into effect in 1781 .

\section{Articles of Confederation}

Driven by an unwillingness by the states to relinquish their independence to a strong central power for fear of abuses, the Articles of Confederation created a central government with very little power. There was to be no president or head of state and no judiciary. The only national body was a unicameral (having only one chamber) Congress, made up of delegates 
from the thirteen states. The Congress was responsible for conducting foreign affairs, declaring war and peace, maintaining an army and navy and a variety of other lesser functions. But the Articles denied Congress the power to collect taxes, regulate interstate commerce or enforce laws.

The new system proved unworkable. Suffering financially from the effect of the war, the economies of the states were in trouble, with farmers hit particularly hard. Trade disputes grew between various states, exacerbated by the fact that no standard national currency had been established. Protests sprung up across America, with some descending into violence. The tensions between states was not calmed by the fact that nine states had organised their own armies, and in some cases, navies as well.

It was soon recognised that a stronger national government had become necessary to ensure the peaceful survival of the states. To this end the leaders of the states met at the Federal Convention in the Philadelphia State House in May 1787. The initial purpose was to amend the Articles of Confederation, but before long the leaders had agreed that an entirely new system was needed. On 17 September 1787, after sixteen weeks of deliberation, thirty-nine of the forty-two delegates put their signature to the new Constitution of the United States of America. Two years later the document had been ratified by the required number of states and the first Congress of the United States of America convened in New York City.

\section{The Constitution of the United States}

Although the Constitution established a central government with far more authority than the one created under the 
Articles of Confederation, this did not mean the states had overcome their fear of despotism. The system of government laid out in the Constitution was deliberately designed to prevent any abuse of the rights of the states. It did this by creating a federal system based on the principle of separation of powers

\section{Federalism}

There was never a question that the new United States of America would be anything other than federal. A federal state maintains more than one level of government, with each having their own rights and independence. Unlike in Britain, where the government in London is pre-eminent, and can create, alter or abolish local governments as it sees fit, the new US Constitution maintained the autonomy of the individual states. They created a central, or federal, government with certain powers and responsibilities out of necessity. As the failure of the Articles of Confederation showed, there were certain jobs, necessary for the success of the new nation, that could not be carried out by the state governments alone. However, under the new Constitution, the state governments were intended to be the primary level of government, with responsibility for their own affairs and those of their citizens. The federal government was to be restricted to those areas which fell outside of the individual state: regulating trade between states, establishing a national currency, conducting foreign affairs and controlling the national military forces. This ideal where each level of government had its own distinct areas of influence which did not cross was known as dual federalism. As we will see, such a pure form of federalism was going to be short lived, but for the early years of the United States it was the state governments which held the power. 
Separation of powers

The Founding Fathers were aware that, whatever their intentions, without some form of safeguard, the powers given to the federal government could be abused. To counter such an eventuality, a system of checks and balances within the federal government itself was established. Rather than invest one body or person with full responsibility for the running of the government, the powers were separated out between three distinct and separate bodies: the executive, the legislature and the judiciary. In principle, no decision could be taken without the possibility that it could be checked by one of the other bodies.

\section{Congress in the Constitution}

Just as the Constitution established a system whereby each branch of government would be checked by another, a bicameral legislature was chosen so Congress could in effect act as a check upon itself. For any law to be passed the consent of both chambers would be needed. These two chambers which make up the US Congress were, and are, the House of Representatives and the Senate.

\section{House of Representatives}

One of the central complaints against the former British rulers was that Parliament taxed the people of the colonies but allowed them no representation in the body where such decisions were made. In order to avoid repeating such a wrong in the new United States, the citizens of the states were granted representation in the House of Representatives. Representatives were to be directly elected by popular vote every two years. This short time between elections was to ensure 
that Representatives would remain sensitive to the wishes of their electorate, or face a swift removal. The number of Representatives returned from each state was determined by the size of the state's population.

While the creation of a directly elected chamber in the national legislature was a radical development for the late eighteenth century, this was no modern-style democracy. Voting rights were limited to white male adults, and in some states a property qualification was also added. Furthermore, the House of Representatives would also have to work together, and in some cases compete, with the other chamber of Congress, the US Senate.

\section{Senate}

The creation of the Senate can be viewed as a response to two of the Founding Fathers' concerns. The first was that if left unchecked, the popular House may make rash and unwise decisions. While the people deserved representation, there was a concern that the masses could be swayed into supporting candidates or policies which were not necessarily in the best interests of the United States. There was a danger that such regular elections may lead to the House pursuing shortterm policies. Secondly, there was a fear that with the number of Representatives from each state determined by population, a few larger states could ride roughshod over the wishes of the rest of the House.

To meet these concerns the Senate was designed to be the chamber which represented the states. Each state was given equal representation, returning two Senators, each representing the whole state, regardless of size of population. While the House, with its regular elections, was intended to be responsive to the current concerns of the population, Senators were 
to serve for six-year terms. The length of tenure was designed to allow the Senate to take a longer term view when making their decisions. In addition to this, under the original Constitution, Senators were not subject to election by the voters of each state; rather they were to be appointed by the legislature of their respective states. Free from having to please the masses and with their extended terms of office, the Founding Fathers hoped that the Senate would act as a more sober body, checking any unwise or impetuous proposals which emerged from the House. This situation lasted until 1913 when the Constitution was amended to provide for the direct election of Senators.

\section{Congressional powers and responsibilities}

\section{Legislation}

The primary power and responsibility of Congress is that of legislation. Congress has the sole legislative power; no other body in the United States can make federal legislation (state legislatures can, of course, make legislation for their own state). Bills can only be introduced into Congress by a Representative or Senator, although for the most part a bill can originate in either chamber. For any bill to become law it must pass a majority vote of both the House and Senate.

While Congress possesses sole legislative power, it is subject to the checks and balances written into the Constitution. Once a bill has passed Congress, it must then be sent to the President for his ${ }^{1}$ approval. The President has ten days (excluding Sundays) to exercise one of three options. He can sign the bill into law, he can do nothing allowing (after the ten days) the bill to pass into law without his approval, or he can veto the bill which returns the legislation to Congress preventing it 
becoming law. However, because Congress is the final authority when it comes to legislation, a presidential veto does not end matters. Congress has the power to override a veto if (and it is often a big if) a two-thirds majority can be obtained in a vote in both the House and Senate. If this majority is achieved, the bill will become law despite the objections of the President.

\section{Oversight}

As part of the system of checks and balances, Congress has the power and responsibility to police many of the actions of the executive. While both chambers have a role to play here, it is the Senate which was given the bulk of the responsibility. All presidential appointments, whether they be to the courts, ambassadorships or to the cabinet must be approved by the Senate. Treaties signed by the President only come into effect once ratified by a two-thirds majority of the Senate. While the President is Commander-in-Chief of the Armed Forces, Congress controls the funds needed to run the forces and only the House of Representatives can declare war. As we shall see later, some of these checks proved to be more effective than others.

Congress constantly monitors the behaviour of the executive branch, something which will be examined further in chapter 7. For extreme cases, the Constitution awarded Congress with the ultimate power - the power to remove the President from office. The House of Representatives was given the power of impeachment if the President is guilty of the ambiguous charge of 'high crimes and misdemeanours'. Impeachment, though, does not mean removal from office. That power was reserved for the Senate which, following impeachment by the House, must then try the President for his crimes, and if a two-thirds majority is reached, remove him from office. 


\section{The development of Congress}

The basic structures and principles of Congress at the beginning of the twenty-first century are the same as they were at the end of the eighteenth. The nation of the United States of America, however, has changed dramatically and the federal government has had to adapt to keep pace with these changes.

The Constitution has been amended only twenty-six times since its adoption, and in fact has changed very little. The first ten amendments, known as the 'Bill of Rights' were adopted in 1791 to satisfy state fears that their rights and those of their citizens were not sufficiently protected from abuses by the federal government. These rights included provisions concerning freedom of speech, freedom of association and the right to a fair trial, among others.

Gradually the right to vote was extended throughout the nineteenth and twentieth centuries. Non-white Americans were given the Constitutional right to vote in 1870, women gained equality in this regard in 1920 and the franchise was extended to 18 -year-olds in 1971 . The seventeenth amendment, ratified in 1913, provided for the direct election of Senators.

Many of the changes which have occurred in Congress have not appeared as Constitutional amendments. The role of Congress both in relation to its place in the federal government and within the nation as a whole has changed. The House and Senate have developed separate identities and styles, partly due to the different roles accorded them by the Constitution, and partly due to traditions which have developed over the years.

Congress currently resides in the Capitol Building on Capitol Hill, Washington DC, connected to the White House 
by Pennsylvania Avenue. It first moved to the nation's current capital in 1800, having spent the previous decade in Philadelphia. The building is now surrounded by offices for the Representatives, Senators and their staff and by the Library of Congress. All buildings are connected by a series of underground tunnels and are accessible by any member of public, provided they can pass thorough a security check. In this regard, the United States has one of the most open governments in the world today.

The balance of power within the federal government remained firmly tilted towards Congress throughout the nineteenth century and for the first half of the twentieth. Congress proudly protected its role as the sole source of legislation and resisted any attempts by the presidency to establish legislative leadership. The presidency had quickly established itself in a strong position in regards to foreign policy, but Congress played the dominant role in the areas of domestic policy played by the federal government.

Presidents Theodore Roosevelt (served 1901-09) and Woodrow Wilson (1913-21), the so-called 'progressive Presidents', both attempted to extend the influence of the presidency to areas of domestic policy, particularly the area of business monopolies. Both were unsuccessful as Congress spurned what it saw as an intrusion into its Constitutional role. The whole balance of power changed in 1932 with the election of Franklin Delano Roosevelt to the presidency. President Roosevelt came to the presidency at a time when the United States was suffering from a crippling economic depression. He was elected on a promise to use the federal government to address the problems faced by America. His 'New Deal' programme did much to help the nation out of its problems, but its effect on the political process would be even greater. 
Roosevelt transformed the role of both the presidency and the federal government. Under his leadership the federal government became involved in areas such as welfare, employment and public works which were previously viewed as the preserve of the states. What was also notable was that many of these initiatives came not from Congress, but from the White House. Congress remained the only body with the power to pass legislation, but Roosevelt gave the presidency a leading role in formulating legislation for Congress to consider. Since Roosevelt's time, the President has regularly been an active participant in the legislative process.

While Congress was forced to adapt to the political changes in the late twentieth century, its role remains essentially the same. The extension of the federal government into areas previously reserved for state government has meant that the range of issues Congress must consider has increased dramatically as has the sheer complexity of the legislation it must pass. With the post-New Deal presidency looking to play a more active role in the initiation of legislation, the legislative process became increasingly characterised by co-operation and competition between Congress and the White House.

The balance of power between Congress and the presidency is constantly changing. Until the mid-1970s, academics often wrote of an 'imperial' presidency, which placed the executive as the dominant branch of government, especially in matters of foreign policy. With the failure of the war in Vietnam and the resignation of President Nixon following the Watergate scandal, both of which highlighted abuses of power by the White House, Congress began to reassert its power not only to check the presidency, but also in terms of its legislative role. Today the struggle for dominance over the direction of the federal government is a much more dynamic one. 


\section{Conclusion}

The primary role of Congress in the American political system remains the same as when the Founding Fathers wrote the Constitution in 1787; all legislative power is still vested in a Congress of the United States, which consists of a Senate and House of Representatives. What has changed is the political and social context within which it operates. The latest change which Congress has had to adapt to came in 1994 when, in the mid-term election, the voters chose to elect a Republican majority in both the House of Representatives and the Senate for the first time since 1955. The following chapters aim to give an understanding of how Congress operates, both internally and within the wider political system. As part of this task, events since 1994 will play a prominent part in the explanation to show how Congress has adapted to the latest developments in American politics.

\section{Notes}

1 Masculine pronouns are used for convenience of style and are not intended to exclude females. 